\title{
Racial Differences in Secondary Hyperparathyroidism
}

\author{
Akihiko Kato ${ }^{1, *}$ \\ ${ }^{1}$ Blood Purification Unit, Hamamatsu University Hospital, Hamamatsu, Japan \\ *Corresponding author: Akihiko Kato, Blood Purification Unit, Hamamatsu University Hospital, 1-20-1 Handayama, Higashi-ku, Hamamatsu, 431-3192, Japan. Tel/Fax: +81-534352756, \\ E-mail:a.kato@hama-med.ac.jp.
}

Received: December 03, 2012; Accepted: December 16, 2012

Keywords: Renal Dialysis; Parathyroid Hormone

\section{Dear Editor,}

I have recently read an interesting paper by Dr. Seck who had examined the prevalence of CKD-MBD in black African (Senegalese) patients on regular hemodialysis (HD) in a cross-sectional fashion (Nephrol-Urol Mon. 2012; 4(4): 613-616) (1). They showed that 57 out of the 79 patients complicated with CKD-MBD (72\%) had a high turnover bone disease with a mean level of $984 \mathrm{pg} / \mathrm{mL}$ of intact parathyroid hormone (iPTH). Because mean calcium and phosphorous levels were not elevated ( 8.6 and $4.85 \mathrm{mg}$ / $\mathrm{dL}$ ), this marked increment of iPTH may be related to racial differences in the regulation of vitamin D-PTH axis.

Autopsy studies have demonstrated that parathyroid mass is increased in blacks compared with whites (2). There is a 4.4-fold higher risk for severe secondary hyperparathyroidism (iPTH $>500 \mathrm{pg} / \mathrm{mL}$ ) in black patients than in white patients at dialysis initiation (3). African-American HD patients have iPTH levels that are higher than expected in relation to bone histology (4). Blacks with advanced CKD not yet on dialysis also have lower $25(\mathrm{OH})$ $\mathrm{D}$ and higher iPTH concentrations with declining kidney function compared with whites, independent of FGF-23 concentrations (5). So, there may be a unique mechanism by which blacks develop secondary hyperparathyroidism, such as skeletal resistance to PTH, or more activation of calcium-sensing receptor in the parathyroid gland. Although current guidelines on the management of CKD-MBD recommend screening and treating abnormal- ities in mineral metabolism, none of them take into account for racial differences. Thus, further evaluation will be needed to realize whether current guidelines are truly adequate for all races/ethnicities.

\section{Authors' Contribution}

A. Kato made substantial contributions to conception, interpretation of data, and drafting of manuscript.

\section{Financial Disclosure}

There was no conflict of interest.

\section{References}

1. Seck SM, Dahaba M, Ka EF, Cisse MM, Gueye S, Tal AO. Mineral and bone disease in black african hemodialysis patients: a report from senegal. Nephrourol Mon. 2012;4(4):613-6.

2. Bell NH, Greene A, Epstein S, Oexmann MJ, Shaw S, Shary J. Evidence for alteration of the vitamin D-endocrine system in blacks. JClin Invest. 1985;76(2):470-3.

3. Gupta A, Kallenbach LR, Zasuwa G, Divine GW. Race is a major determinant of secondary hyperparathyroidism in uremic patients. J Am Soc Nephrol. 2000;11(2):330-4.

4. Moore C, Yee J, Malluche H, Rao DS, Monier-Faugere MC, Adams E, et al. Relationship between bone histology and markers of bone and mineral metabolism in African-American hemodialysis patients. Clin J Am Soc Nephrol. 2009;4(9):1484-93.

5. Jovanovich A, Chonchol M, Cheung AK, Kaufman JS, Greene $\mathrm{T}$, Roberts WL, et al. Racial differences in markers of mineral metabolism in advanced chronic kidney disease. Clin J Am Soc Nephrol. 2012;7(4):640-7. 